\title{
Pheretima javanica K. Ethanol Extract Granules' Effects on Eosinophil Level, Immunoglobulin E Level, and Organs Histopathology in Rattus norvegicus B.
}

\author{
Dwi Wahyuni*, Joko Waluyo, Jekti Prihatin, Fersty Isna Kusumawardani, Aditya Kurniawan \\ Biology Education Study Program, Department of Mathematic and Nature Education, Faculty of Teacher Training and Education, Universitas Jember, \\ Jl. Kalimantan Tegalboto No.37, Jember, Indonesia \\ ${ }^{*}$ Corresponding author. E-mail: dwiwahyuniwiwik.fkip@unej.ac.id
}

Received date: Sep 8, 2020; Revised date: Apr 9, 2021; Accepted date: May 11, 2021

\section{Abstract}

B ACKGROUND: Traditional medicine that might be useful to treat typhoid fever is earthworms (Pheretima javanica $\mathrm{K}$.). It is important to know whether any substances contained in Pheretima javanica K. extract are toxic and have pharmacological effects, which can be observed from the eosinophil and immunoglobulin $\mathrm{E}$ (IgE) levels in the blood.

METHODS: Thirty Rattus norvegicus B. were included in this study and were separated into 5 groups, with 6 rats in each group. T1, T2, T3, and T4 were groups of rats treated with $50,300,2000$, and $5000 \mathrm{mg} / \mathrm{kg}$ BW of Pheretima javanica $\mathrm{K}$. ethanol extract granules (PJEEG), respectively, while the control group was a group of rats treated with $0.36 \mathrm{mg}$ Ciprofloxacin. The eosinophil number and the $\operatorname{IgE}$ concentration were detected. Physical observations were also conducted to detect any allergic symptoms, toxicity symptoms, or histopathological changes.
RESULTS: Administration of PJEEG significantly increased the number of eosinophil in every group, from 49.82 cells $/ \mu \mathrm{L}$ to 259.26 cells $/ \mu \mathrm{L}$ on average $(p<0.001)$. PJEEG did not significantly affect IgE levels $(p=0.624)$. The results showed that the administration did not cause any allergic and toxicity symptoms. Histopathological analysis of rats' kidneys and liver also showed that the administration had no significant effect on histopathological changes.

CONCLUSION: The administration of PJEEG does not cause allergic symptoms, toxicity symptoms, and histopathological changes in rats. The administrations also significantly increase eosinophil number in rats' blood. However, the concentration of IgE in rats' blood was not significantly changed after administration of PJEEG.

KEYWORDS: allergies, typhoid fever, earthworms, Pheretima javanica K., eosinophil, immunoglobulin E

Indones Biomed J. 2021; 13(2): 208-15

\section{Introduction}

Typhoid fever is a non-communicable disease caused by the infection of bacteria, which now has become a global health problem.(1) Antibiotics are usually used for typhoid fever therapy, however, inappropriate use of antibiotics might cause the bacteria to become more resistant towards it. $(2,3)$ Therefore, various research and developments utilizing technological advancements have been carried out to improve the quality and safety of therapy products, including traditional medicines. The development of traditional medicine is sought to be in line with modern medicine.

Traditional medicine that might be useful to treat typhoid fever is earthworms (Pheretima javanica K.). Pheretima javanica K. is known to contain active compounds of alkaloids, which have antibacterial and antipyretic activity.(4,5) To obtain the active compound from the desired earthworms, an extraction process should be done.(6) A 25\% concentration of antibacterial substances of Pheretima javanica K. has effectively reduced typhoid fever symptoms in white rats (Rattus norvegicus B.).(7,8) 
The use of conventional ethanol extracts of Pheretima javanica K. for typhoid fever treatment has several disadvantages because it is sticky, not durable, easily polluting the environment, and difficult to be dissolved in solvents. Therefore, some researchers changed the form of Pheretima javanica K. ethanol extract into granules. Granules have several advantages since they are resistant to air influence and are easily moistened by solvents. Therefore, it was expected that the use of Pheretima javanica $\mathrm{K}$. ethanol extract therapy in granules forms can increase people's interest and the practicality in taking herbal medicines.(9)

Even though most traditional medicines are known to have lower side effects (10), however, it is important to know whether any substances contained in Pheretima javanica $\mathrm{K}$. ethanol extract granules (PJEEG) are toxic and have pharmacological effects in the form of allergic symptoms. One of the essential tests in identifying the pharmacological effects of allergic reactions is the immunogenic test. It can be observed from the eosinophil and the immunoglobulin E (IgE) levels in white rats' blood. For over 100 years, eosinophil has been associated with allergic disease and is known as a good biomarker for allergies.(11) While a high amount of $\operatorname{IgE}$ is generally considered as a diagnostic factor of allergic diseases and other mediating disorders.(12)

Since not many studies reporting the effect of Pheretima javanica $\mathrm{K}$. extract for typhoid therapy, in this study, we determined the level of eosinophil and IgE in white rats' blood before and after the administration of PJEEG. To determine the allergic effect, we also conducted a direct observation of allergy symptoms in the white rats' bodies. Meanwhile, white rats' kidney and liver histopathology were analyzed as a reference to determine whether the PJEEG has any acute toxicity effect or not.

\section{Methods}

\section{Preparation of Experimental Animals}

Experimental animals (Rattus norvegicus B.) were chosen with the following criteria: male rats, strain Wistar, in a healthy condition, aged 3-4 months, and weighted 200250 grams. Rats were put in a cage with the lighting condition of bright for 12 hours and dark for 12 hours, with a temperature of $25^{\circ} \mathrm{C}$ and $80 \%$ humidity. Acclimatization was carried for seven days upon the rats' arrival at the study site to homogenize and observe the rats' requirements before administering the treatment with PJEEG. The rats were then placed in cages according to the type of treatment given. This study was approved by the Research Ethics Committee of Faculty of Medicine, Universitas Jember (No. 1.119/H.25.1.11/KE/2017).

\section{Production of PJEEG}

Pheretima javanica $\mathrm{K}$. were nurtured and obtained from the Biomedical Laboratory, Faculty of Medicine, Universitas Jember. Pheretima javanica K. were washed and then dried for 4-7 days under the sun. After completely dried, the earthworms were heated at $40^{\circ} \mathrm{C}$ for 4 hours and blended until it became powder. The earthworm powder was macerated with $70 \%$ ethanol in a ratio of $1: 3$ for three days. The maceration results were filtered, rotated, evaporated, and roasted. The extracts were mixed with the dryer in a ratio of 1:1. The mixture was then roasted again and sieved. PJEEG were prepared with the doses of 50, 300, 2000, and $5000 \mathrm{mg} / \mathrm{kg}$ body weight (BW) and later were dissolved with sterile water.

\section{Administration of PJEEG}

Administration of PJEEG was carried out by oral method (gavage) using a probe on day- 8 to day-14 for 7 days. Granules were given after measuring the rats' weight to facilitate the calculation of the given dose. The rats were separated into 5 groups, with 6 rats in each group. T1, T2, $\mathrm{T} 3$, and $\mathrm{T} 4$ were groups of rats treated with 50, 300, 2000, and $5000 \mathrm{mg} / \mathrm{kg} \mathrm{BW}$ of PJEEG, respectively, while the control group (C) was a group of rats treated with $0.36 \mathrm{mg}$ Ciprofloxacin.

\section{Immunogenic Test}

Blood extraction of the white rats was carried out through the eye's orbital plexus by using microhematocrit tubes on day- 0 and day- 9 . One $\mathrm{mL}$ of each white rat's blood was collected to examine the eosinophil level. The blood was put in ethylenediaminetetraacetic acid (EDTA) tube before finally examined by using Sysmex XN 450 Hematology Autoanalyzer (Sysmex, Kobe, Japan) with fluorescent flowcytometry methods.

Another $1 \mathrm{~mL}$ of blood was drawn to examine the concentration of IgE. The blood was inserted in a tube without EDTA, before got centrifuged to get the serum. The sample was then examined with an IgE Enzyme-linked Immunosorbent Assay (ELISA) Kit (Bio-Rad Laboratories, Hercules, CA, USA).

\section{Observation of Rats' Allergy Symptoms}

The observation of the white rats' allergy symptoms was carried out before the administration of PJEEG and 24 hours 
after the administration. If rats were found to have rash, redness, bumps, and inflammation on the surface of their skin, it was assumed that they got the symptoms of allergy after the administration of PJEEG.

\section{Observation of Rats' Body Weight and Toxicity Symptom}

Body weight was measured twice a week to see whether there was a change in weight before and after the administration of the extract. The physical and activity observations were also carried out to see the signs of toxic symptoms. The observation of toxicity symptom was conducted after the administration of PJEEG. For the physical observation, we checked whether the rats encountered hair loss or a change of hair color. While for the activity observation, we checked whether the rats were moving abnormally compared to other normal rats or whether it became passive after the PJEEG administration. After the observation of their body weight and toxicity symptom, each rat then was scored based on Body Condition Scoring (BCS) and Assessing Pain and Distress in Mice categories.(13)

\section{Observation of Rats' Organs}

On day-15, all rats were dissected to take the organs, then the organs were dried by using absorbent papers. Afterward, the organs' relative weight was calculated by dividing the body's absolute weight by the body weight.

Microscopic histopathology observation of rats' organs was conducted under the light microscope by an anatomic pathologist. The occurring changes were observed in every field of view. Each slide was observed with $100 \mathrm{x}$ zoom magnification and then followed by 400x zoom magnification for at least five times to avoid observation error.

\section{Statistical Analysis}

SPSS software ver. 21 (IBM Corporation, Armonk, NY, USA) was used to analyze the data. One-Way ANOVA tests with a significance of $p<0.01$ and a $99 \%$ level of confidence interval were used to find the difference before and after the administration of PJEEG. All data were expressed in mean \pm SD.

\section{Results}

\section{Increased Number of Eosinophils}

Table 1 showed the eosinophil level before and after the administration of PJEEG. Every group showed increased number of eosinophils after the administration but remained at the normal level. The average number of eosinophil obtained from the 5 groups before the administration was 49.82 cells $/ \mu \mathrm{L}$, while the average number after the administration was 259.26 cells $/ \mu \mathrm{L}$.

The average eosinophil level before and after the administration of PJEEG showed that $p$-value $=0.000$, indicating that there was a significant change in eosinophil number in rats' blood after the administration.

\section{No Significant Change of IgE Level}

The IgE level before and after the administration of PJEEG was presented in Table 2. The average IgE level of the 5 groups before the administration was $24.72 \%$, while the average IgE level after the administration was $24.02 \%$. With the standard limit of IgE serum levels of $105-128 \%$, no groups exceeded the normal limit of IgE serum level, showing that there was no indication of allergies.

The increase in the concentrations of $\operatorname{IgE}$ only occurred in T1 and T2 groups. Meanwhile, T3 and T4 groups exhibited a decrease in concentration after the administration of PJEEG. Similar to T3 and T4, the mean IgE level in the control group also showed a decrease in the concentration after the administration of PJEEG.

One-Way ANOVA test result of the average $\operatorname{IgE}$ level before and after the administration of PJEEG showed that $p$-value $=0.624$, meaning there was no significant difference in the concentration of $\operatorname{IgE}$ before and after the

Table 1. Number of eosinophils before and after the administration of PJEEG.

\begin{tabular}{cccc}
\hline Group & \multicolumn{3}{c}{$\mathbf{M} \pm \mathbf{S D}$} \\
\cline { 2 - 4 } & $\begin{array}{c}\text { Eosinophil Before the } \\
\text { Administration } \\
(\mathbf{c e l l} / \boldsymbol{\mu L})\end{array}$ & $\begin{array}{c}\text { Eosinophil After the } \\
\text { Administration } \\
(\text { cell/ } \boldsymbol{\mu L})\end{array}$ & $\begin{array}{c}\text { Difference } \\
(\text { cell/ } \boldsymbol{\mu L})\end{array}$ \\
\hline $\mathrm{C}$ & $32.5 \pm 26.3$ & $224.5 \pm 120.1$ & $192.0 \pm 93.8$ \\
$\mathrm{~T} 1$ & $67.3 \pm 94.8$ & $223.0 \pm 140.6$ & $155.8 \pm 45.8$ \\
$\mathrm{~T} 2$ & $32.5 \pm 20.6$ & $255.0 \pm 104.6$ & $222.5 \pm 84.1$ \\
$\mathrm{~T} 3$ & $56.8 \pm 49.8$ & $290.0 \pm 125.9$ & $233.3 \pm 76.1$ \\
$\mathrm{~T} 4$ & $60.0 \pm 55.9$ & $303.8 \pm 129.9$ & $243.8 \pm 73.9$ \\
\hline
\end{tabular}


Table 2. IgE level before and after the administration of PJEEG.

\begin{tabular}{cccc}
\hline \multirow{2}{*}{ Groups } & \multicolumn{3}{c}{$\mathbf{M} \pm \mathbf{S D}$} \\
\cline { 2 - 4 } & $\begin{array}{c}\text { IgE Before the } \\
\text { Administration (\%) }\end{array}$ & $\begin{array}{c}\text { IgE After the } \\
\text { Administration (\%) }\end{array}$ & Difference (\%) \\
\hline $\mathrm{C}$ & $33.43 \pm 24.49$ & $25.75 \pm 28.7$ & $7.68 \pm 4.24$ \\
$\mathrm{~T} 1$ & $30.03 \pm 6.42$ & $40.18 \pm 22.12$ & $10.15 \pm 15.70$ \\
$\mathrm{~T} 2$ & $14.15 \pm 11.79$ & $17.28 \pm 11.42$ & $3.13 \pm 0.37$ \\
$\mathrm{~T} 3$ & $20.08 \pm 14.35$ & $19.20 \pm 7.14$ & $0.88 \pm 7.14$ \\
$\mathrm{~T} 4$ & $25.93 \pm 15.17$ & $17.68 \pm 13.73$ & $8.25 \pm 1.44$ \\
\hline
\end{tabular}

administration, or that the application of PJEEG did not significantly influence the IgE level in Rattus norvegicus $\mathrm{B}$.

\section{No Allergic Symptom}

The observation of the allergic symptoms showed that the rats did not show any signs of allergic symptoms. On the surface of the rats' skin, there were no rashes, no redness, no bumps, and no inflammation in all the treatment groups. It indicated that the application of PJEEG had no effect on Rattus norvegicus B., which was indicated by the absence of allergic reactions and symptoms in all the treatment groups.

\section{No Significant Change in Rats' Body Weight and No Toxicity Symptom}

The toxicity symptoms observation showed that the rats in all groups obtained score 1, which was indicated by the well-cared hair, sensitivity to stimulation, in a good condition, calm or sleeping, and had a normal appetite. This also meant that after 14 days of the administration, all rats were considered normal based on the Assessing Pain and Distress in Mice categories.

Some rats showed that the body condition was neither thin nor obese, and the vertebrae and dorsal pelvic bone were not obtrusive but can still be rubbed by giving a little hand pressure $(\mathrm{BCS}=3)$. While some rats' body condition showed to be quite fat, the characteristics shown by the vertebrae part were almost unseen, a strong pressure must be done to feel the vertebrae part of the rats' body $(\mathrm{BCS}=4)$.
Table 3 showed rats' body weight before the administration of PJEEG and after 14 days of the administration. Meanwhile, Figure 1 showed the changes in rats' weight from before the administration to 14 days after the administration. All the rats experienced weight gain after the administration. These data showed that there was an increase in the average body weight of $14.3 \%$.

Even though the graph showed increase of body weight, after the body weight was analyzed using OneWay ANOVA, and it was obtained that $p$-value $=0.295$. This meant that there was no significant difference of rats' body weight before and after the administration of PJEEG.

\section{No Significant Changes in Rats' Morphology and Histopathology Results}

Table 4 showed the morphology observation results, consist of the relative weight calculation and the morphology condition, of rats' kidney and liver after the organs were dissected. It was shown that all the rats from 5 groups had brownish-red kidneys and brownish-red livers. The obtained $p$-value for the kidney before and after the administration was 0.138 , while the $p$-value for the liver was 0.757 . These results showed that PJEEG did not significantly affect the relative weight of the white rats' kidneys and liver.

Figure 2 showed the histopathology result of the rats' kidneys after the administration of PJEEG, meanwhile Figure 3 showed the histopathology result of the rats' livers after the administration. The histopathological observation

Table 3. The observation result of toxicity symptom.

\begin{tabular}{cccc}
\hline \multirow{2}{*}{ Groups } & \multicolumn{3}{c}{$\mathbf{M} \pm$ SD } \\
\cline { 2 - 4 } & $\begin{array}{c}\text { Body Weight Before the } \\
\text { Administration (g) }\end{array}$ & $\begin{array}{c}\text { Body Weight After the } \\
\text { Administration (g) }\end{array}$ & Difference (g) \\
\hline C & $226.0 \pm 11.5$ & $263.8 \pm 19.5$ & $37.8 \pm 10.9$ \\
T1 & $232.4 \pm 13.3$ & $261.0 \pm 12.7$ & $28.6 \pm 2.4$ \\
T2 & $235.2 \pm 6.9$ & $259.6 \pm 10.8$ & $24.4 \pm 11.1$ \\
T3 & $246.8 \pm 6.6$ & $266.8 \pm 20.1$ & $20.0 \pm 18.6$ \\
T4 & $243.4 \pm 7.7$ & $272.2 \pm 13.8$ & $28.8 \pm 15.1$ \\
\hline
\end{tabular}




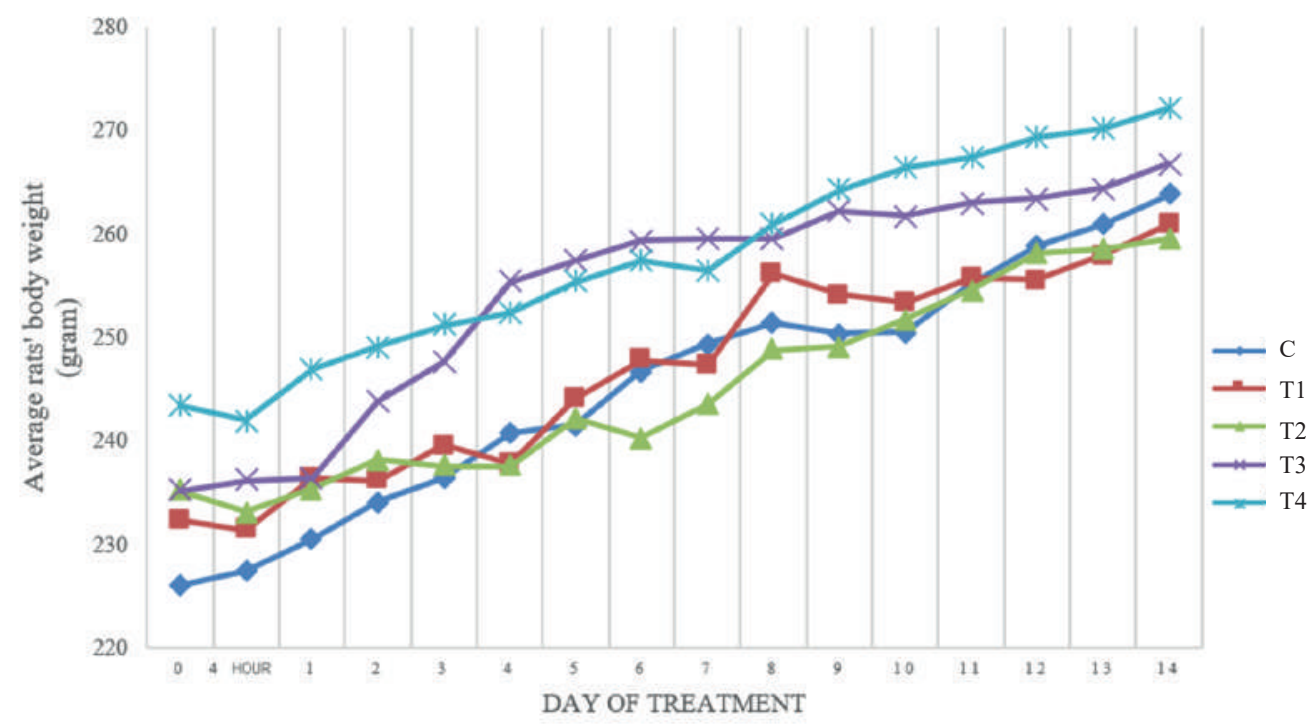

Figure 1. The changes of rats' body weight during 14 days of study.

of kidney and liver in the control and all treatment groups showed that all rats experienced hydropic degeneration. Based on the results of the One-Way ANOVA test, the analysis showed a $p$-value $>0.05$, suggesting that the administration of the extract gave no significant effect on the changes in the histopathology of rats' kidneys and liver.

We also conducted an observation of the death of the experimental animal after the first 4 hours, the early 24 hours, and 14 days. There was no mortality of rats after being induced by PJEEG at the doses of 50, 300, 2000, and $5000 \mathrm{mg} / \mathrm{kg} \mathrm{BW}$. All rats remained alive at the end of the study. Based on the data, the lethal dose (LD) $)_{50}$ value of PJEEG was more than $5000 \mathrm{mg} / \mathrm{kg} \mathrm{BW}$.

\section{Discussion}

The main function of eosinophils is fighting microbial pathogens that cannot easily be destroyed. Eosinophil cells do not only recognize the antigen but also phagocyte the antigen and present an antibody to the blood.(11) The results of this study show a significant increase in the number of eosinophils after the administration of PJEEG. The eosinophil test results show a small number of eosinophil levels before the PJEEG administration. With the average eosinophil level in blood is $100-500$ cells $/ \mu \mathrm{L}(14)$, all 5 groups have an average eosinophil level below the standard limit, which means that the rats have low immune responses toward infections or allergens that enter the body. However, after the administration of PJEEG, the eosinophil levels of the rats' blood have increased to normal levels. Increase in the number of eosinophils might be caused by the improvement in rats' immune response to the allergens that enter their bodies.

Eosinophils' effector function is mediated by the degranulation process which is mediated by $\operatorname{IgE}$ or other chemotactic factors.(15) In this study, it is shown that only the rats that were induced with 2000 and $5000 \mathrm{mg} / \mathrm{kg} \mathrm{BW}$ of PJEEG experiencing a decrease of IgE level, while rats induced with 50 and $300 \mathrm{mg} / \mathrm{kg} \mathrm{BW}$ of PJEEG are not. This decrease of IgE levels indicates the absence of allergens that enter the body, in this case, it wasthe PJEEG. This suggests

Table 4. Morphology observation of rats' organs after 14 days of PJEEG administration.

\begin{tabular}{|c|c|c|c|c|}
\hline \multirow[b]{2}{*}{ Groups } & \multicolumn{2}{|c|}{ Kidney } & \multicolumn{2}{|c|}{ Liver } \\
\hline & $\begin{array}{c}\mathrm{M} \pm \text { SD } \\
\text { Relative Weight (g) }\end{array}$ & $\begin{array}{c}\text { Morphology } \\
\text { Condition }\end{array}$ & $\begin{array}{c}\qquad \mathrm{M} \pm \mathrm{SD} \\
\text { Relative Weight (g) }\end{array}$ & $\begin{array}{c}\text { Morphology } \\
\text { Condition }\end{array}$ \\
\hline $\mathrm{C}$ & $0.0098 \pm 0.0012$ & Brownish red & $0.0332 \pm 0.0006$ & Brownish red \\
\hline $\mathrm{T} 1$ & $0.0081 \pm 0.0002$ & Brownish red & $0.0345 \pm 0.0029$ & Brownish red \\
\hline $\mathrm{T} 2$ & $0.0097 \pm 0.0013$ & Brownish red & $0.1355 \pm 0.1745$ & Brownish red \\
\hline $\mathrm{T} 3$ & $0.0088 \pm 0.0008$ & Brownish red & $0.0327 \pm 0.0004$ & Brownish red \\
\hline $\mathrm{T} 4$ & $0.0080 \pm 0.0002$ & Brownish red & $0.0345 \pm 0.0035$ & Brownish red \\
\hline
\end{tabular}



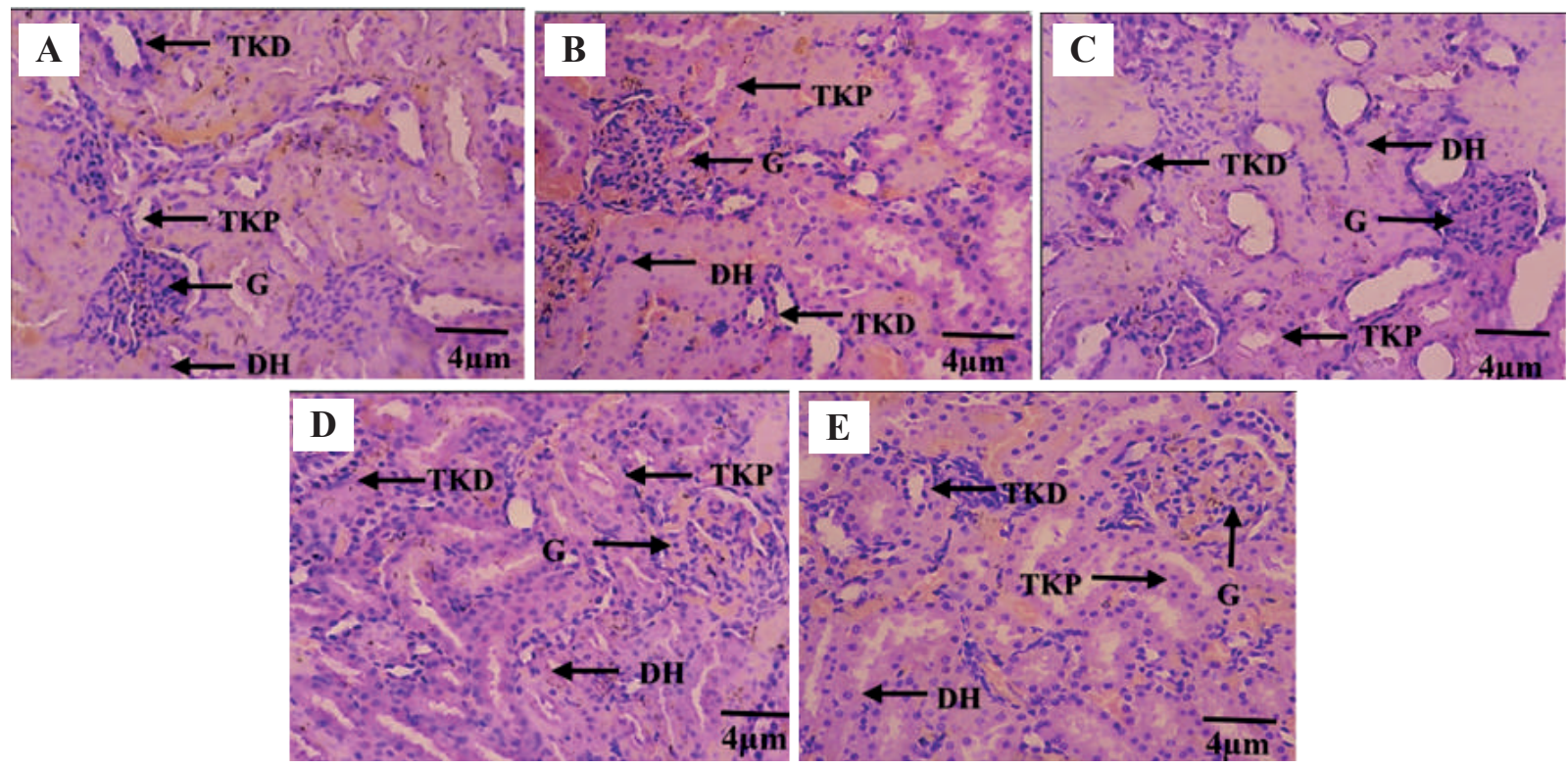

Figure 2. Histopathology result of rats' kidney after the administration of PJEEG. G: Glomerulus; TKP: Tubulus Contortus Proximal; TKD: Tubulus Contortus Distal; DH: Hydrophic Degeneration. A: C group; B: T1 group; C: T2 group; D:T3 group: E: T4 group.

that only larger doses of PJEEG can reduce IgE levels in rats.

IgE emerges because of the body's response to the presence of allergens. Once $\operatorname{IgE}$ is formed due to a reaction of an allergen, by the next time the same type of allergen enters the body, IgE will cause an allergic reaction. Pheretima javanica $\mathrm{K}$. has an antimicrobial bioactive peptide compound and mostly consist of amino acids or proteins, hence they do not cause pharmacological effects such as allergies.(16)
The result of this study shows that neither the control group nor the treatment groups show any signs of allergic symptoms, indicating that the administration of PJEEG has no allergic effect on rats. The use of Ciprofloxacin in this study is intended to compare the allergic reactions that arise due to the use of these two materials. It is already well known that Ciprofloxacin is highly effective for the treatment of typhoid fever.(17)

Assessing whether the rats are having toxicity symptoms or not is an effective tool to indicate when
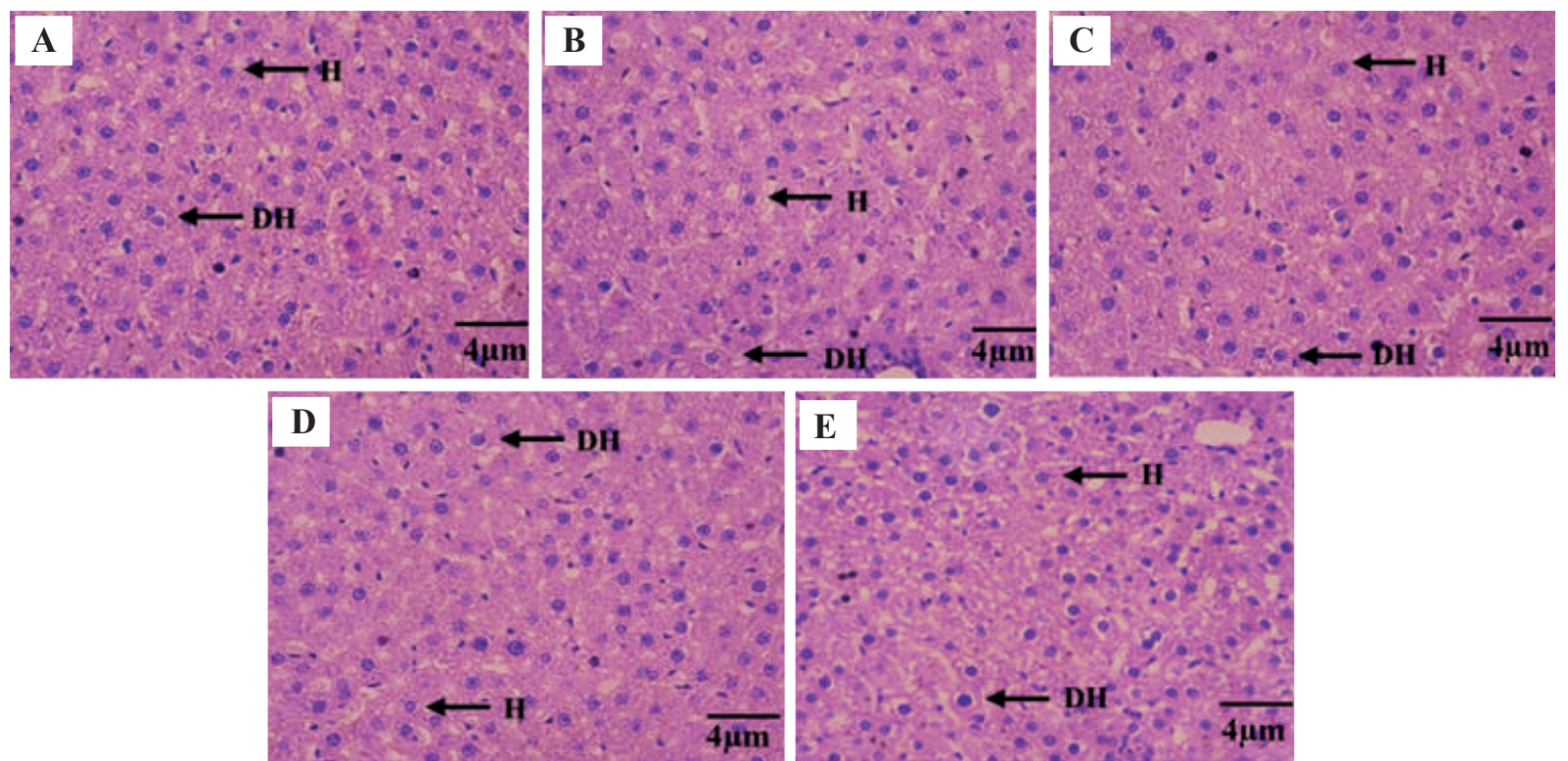

Figure 3. Histopathology result of rats' liver after the administration of PJEEG. DH: Hydrophic Degeneration; H: Normal Hyaline. A: C group; B: T1 group; C: T2 group; D:T3 group: E: T4 group. 
an animal's condition is deteriorating or has reached a clinical endpoint.(13) Based on the observation after 14 of administration, all rats included in this study are shown to be in normal condition, which was also indicated by the BSC of either 3,4 , or 5 . This suggests that the administration of PJEEG does not affects rats' body condition.

The changes in body weight in the experimental animals may also reflect the toxicity symptoms that occurred after the administration o PJEEG. In this study, the administration gives no significant effect on the increase of rats' body weight $(p>0.05)$. It suggests that one-time administration of PJEEG do not cause excessive weight gain in rats that leads to obesity. Weight gains are occurring because the rats are in a healthy state, which is characterized by a steady and increased appetite.(13) Protein in Pheretima javanica $\mathrm{K}$. contains essential amino acids with the quality exceeding fish and meat.(18) It also contains fibrinolytic enzymes, which are useful in repairing tissues in the digestive system. Fibrinolytic enzyme can also improve body performance and increases appetite.(19,20)

The morphology observation of this study shows that there is no color difference between the rats' kidneys and livers in the control group and the treatment groups. All rats are found to have brownish-red color, similar to the color of normal kidney and liver. The brownish-red color was caused by a large amount of blood flowing to the organs facilitated by the blood vessels.(21) The observation of the organ's color is related to the condition of blood flow in rats' bodies. If the extract were toxic, it would disrupt the blood flow in the rats' kidneys and liver, which would be characterized by pale-colored organs. A toxic extract would cause fatty tissue to interfere with the blood flow, resulting in pale-colored organs.(22)

Because kidney and liver are the main organs affected by metabolic responses of toxic substances, it is important to calculate the relative weight of organs to find whether there is organ damage caused by the metabolic response or not.(23) This study shows that there is no significant effect on the relative weight of kidney and liver of the white rats between the treatment groups and the control group $(p>0.05)$. The extract consumed by rats does not accumulate in the kidney and liver and does not cause blood clots to clog. If the extract were toxic, a blood flow disruption in the kidneys and liver would occur. This condition causes the kidneys and liver to be swollen, which ultimately affects their normal function.

From the results, it was known that all the groups experienced hydropic degeneration without the presence of inflammatory cells. Cell damage in hydrophic degeneration is considered harmless because the damage to hydrophic deterioration is included in mild and reversible injuries. If the extract was toxic, it would cause the tissue cells to necrosis.(24) The statistical analysis also suggests that the administration of PJEEG have no significant effect on the changes in the histopathology of kidneys and liver, similar to the result of the Ciprofloxacin induced group.

The observation of this study also shows that there is no mortality of experimental animals after being induced by PJEEG at the doses of 50, 300, 2000, and $5000 \mathrm{mg} / \mathrm{kg}$ $\mathrm{BW}$, indicating that these doses are safe to be consumed. Hence this study shows that the use of PJEEG as traditional medicine can be classified as a practically non-toxic medicine.

\section{Conclusion}

The administration of PJEEG does not cause allergic symptoms, toxicity symptoms, and histopathological changes in rats' body and its organs. The administrations also significantly increase eosinophil number in rats' blood, from under the standard limit to the normal limit. However, the concentration of IgE in rats' blood was not significantly changed but it remains at a safe concentration level after administration of PJEEG.

\section{Authors Contribution}

DW and JW were involved in the research conception. JW and AK were involved in the data acquisition, while DW, JP, and FIK analyzed the data. DW, JW, JP, AK interpreted the study results. DW, JW, JP, were involved in the manuscript preparation, while FIK and AK design the figure and table. All authors took parts in giving critical revision of the manuscript.

\section{References}

1. Nurtamin T, Nurman RY, Hafizah I. Antibacterial activity of eel (Anguilla spp.) mucus against Salmonella typhi. Indones Biomed J. 2016; 8: 179-82.

2. Patil N, Mule P. Sensitivity pattern of salmonella typhi and paratyphi a isolates to chloramphenicol and other anti-typhoid drugs: An in vitro study. Infect Drug Resist. 2019; 12: 3217-25.

3. Britto CD, Wong VK, Dougan G, Pollard AJ. A systematic review of antimicrobial resistance in Salmonella enterica serovar Typhi, the etiological agent of typhoid. PLoS Negl Trop Dis. 2018; 12 : e0006779. doi: 10.1371/journal.pntd.0006779.

4. Omar HM, Ibraheim ZZ, El-shimy NA, Ali RS. Anti-inflammatory, 
antipyretic and antioxidant activities of the earthworms extract. J Biol Earth Sci. 2012; 2: B10-7.

5. Li W, Li S, Zhong J, Zhu Z, Liu J, Wang W. A novel antimicrobial peptide from skin secretions of the earthworm, Pheretima guillelmi (Michaelsen). Peptides. 2011; 32: 1146-50.

6. Zulharmitta Z, Kasypiah U, Rivai H. Preparation and characterization of dry guava leaf extract (Psidium guajava L.). J Farm Higea. 2017; 4: 147-57.

7. Supriyanto, Waluyo J, Hariyadi S. Detection, Isolation and Characterization of Antibacterial Compounds Pheretima Javanica (Horst) as Typhoid Drugs (In Vivo). Jember: Universitas Jember; 2010.

8. Waluyo J, Wahyuni D, Utami WS. Healing effects of fresh earthworms (Pheretima Javanica K.) for typhoid fever induced in male white rat (Rattus norvegicus L.). Int J Recent Technol Eng. 2019; 8: 2012-4.

9. Setiana IH, Kusuma ASW. Effervescent granule formulations rom various herbs. Farmaka. 2012; 16: 9-17.

10. Yuan H, Ma Q, Ye L, Piao G. The traditional medicine and modern medicine from natural products. Molecules. 2016; 21: 559. doi: 10.3390/molecules21050559.

11. Jatmiko SW. Eosinophil as antigen presenting cell. Bioeksperimen J Penelit Biol. 2015; 1: 18-23.

12. Shoormasti RS, Pourpak Z, Eshraghian M, Ashtiani MH, Jamali M, Ziedi M, et al. The study of total IgE reference range in healthy adults in Tehran, Iran. Iran J Public Health. 2010; 39: 32-6.

13. Burkholder T, Foltz C, Karlsson E, Linton CG, Smith JM. Health evaluation of experimental laboratory Mice. Curr Protoc Mouse Biol. 2012; 2: 145-65.

14. Fahrimal Y, Eliawardani, Rafina A, Al Azhar, Asmilia N. White rat blood profile (Rattus norvegicus) infected by trypanosoma evansi and given with jaloh stem skin extract (Salix tetrasperma Roxb). J Kedokt Hewan; 2014; 8: 164-8.
15. Aristizábal B, González Á. Chapter 2 Innate immune system. In: Anaya JM, Shoenfeld Y, Rojas-Villarraga A, editors. Autoimmunity: From Bench to Bedside. Bogota (Colombia): El Rosario University Press; 2013.

16. Hidayat M. Immunoglobulin E levels, the number of eosinophils in filariasis patients with elephantiasis and post-therapy filariasis patients. J Akad Baiturrahim. 2015; 4: 68-80.

17. Akhtar MA, Hussain A, Karamat KA, Naqi N, Zubdi N. Role of ciprofloxacin in typhoid fever. J Pak Med Assoc. 1992; 42: 9-10.

18. Yumaihana Y. Breeding of Perionyx excavatus earthworms using vermiculture techniques of livestock waste and its effect on produced manure. J Peternak Indones; 2007; 12: 142-9.

19. Samatra DPGP, Tjokorda GBM, Sukrama IDM, Dewi NWS, Praja RK, NUrmansyah D, et al. Extract of earthworms (Lumbricus rubellus) reduced malondialdehyde and 8-hydroxy-deoxyguanosine level in male wistar rats infected by salmonella typhi. Biomed Pharmacol J. 2017; 10: 1765-71.

20. Widyasunu CA, Samidja I, Rachmawati D. Substitution of fish meal with earthworm meal (Lumbricus rubellus) in the artificial diet on growth and efficiency of feed utilization tiger grouper (Epinephelus fuscoguttatus). J Aquac Manag Technol. 2013; 2: 38-50.

21. Fitmawati F, Titrawani T, Safitri W. Histological structure of the liver of white rats by giving traditional herbs of the lingga community, Riau Islands. EKOTONIA J Penelit Biol Bot Zool Mikrobiol. 2018; 3: 11-9.

22. Fortes RC. Nutritional implications in chronic liver diseases. J Liver Res Disord Ther. 2017; 3: 131-3.

23. Jothy SL, Zakaria Z, Chen Y, Lau YL, Latha LY, Sasidharan S. Acute oral toxicity of methanolic seed extract of Cassia fistula in mice. Molecules. 2011; 16: 5268-82.

24. Januar R, Yusfiati, Fitmawati. Microscopic structure of the white rat liver. JOM FMIPA. 2014; 1: 392-401. 